Studia Slavica Savariensia 2016. 1-2. 3-6

DOI: $10.17668 /$ SSS.2016.1-2.3

\author{
Karel Gadanji \\ (Sombotel, Madžarska)
}

\title{
POGLED NA KONFERENCE PRETEKLIH 35 LET
}

Današnji dan je zame veliko veselje. Prvič zato, ker sem ga doživel. Drugič pa zato, ker lahko zdaj praznujem skupaj z vami. Pred več kot 35 leti smo zasnovali našo prvo prireditev. Takrat nismo niti pomislili, da se srečamo tudi po 35 letih.

Ko smo leta 1980 ustanovili Katedro za slovenski jezik in književnost, smo skupaj s takrat že deset let delujočo Katedro za ruski jezik in književnost vedeli, da lahko slavistika v Sombotelu živi le tako, da odpre svoja vrata. Izoblikovali smo obsežne strokovne stike tako $\mathrm{z}$ visokošolskimi ustanovami $\mathrm{v}$ Sloveniji, na Hrvaškem in nadaljnjih petnajstih državah kot tudi z madžarskimi univerzami, kjer imajo slavistiko.

Leta 1990 smo ustanovili Katedro za hrvaški jezik in književnost. Katedra ima od začetka pomembno vlogo $\mathrm{v}$ domači kroatistiki in $\mathrm{v}$ naših mednarodnih stikih.

Minulih približno 40 let ni bilo z rožicami postlanih, vendar smo od Pedagoške, kasneje Filozofske fakultete Univerze v Mariboru, vedno dobili pomoč. Brez njihove podpore ne bi mogli obstati. Pomagali so nam takšni odlični strokovnjaki, kot so akademikinja Zinka Zorko, ki se je udeležila vseh naših konferenc, prof. dr. Marko Jesenšek, prof. dr. Janko Čar, Zlata Vokač, Jože Pogačnik, Jože Lipnik, Miran Štuhec, Mihaela Koletnik, Elizabeta Bernjak. Zdaj je naš edini pravi podpornik iz Maribora prorektor univerze, prof. dr. Marko Jesenšek. Z nami so bili tudi strokovnjaki Univerze v Ljubljani.

Tokratno konferenco posvečamo spominu na Avgusta Pavla, ki se je rodil pred 130 leti.

Duhovna dediščina Avgusta Pavla nas obvezuje, da se slovenistika, kroatistika in rusistika, to je slavistika, še naprej ohranja na sombotelski univerzi.

$\mathrm{S}$ prigaranim moramo dobro gospodariti. Kar so naši predniki $\mathrm{z}$ večdesetletnim trdnim delom zgradili in Sombotelu pridobili mednarodni sloves, ne smemo porušiti.

A mostani konferenciát a 130 évvel ezelőtt született Pável Ágoston emlékének szenteljük. Pável Ágoston szellemi öröksége arra kötelez bennünket, hogy a szombathelyi egyetemen a szlovenisztika, kroatisztika, 
ruszisztika vagyis a szlavisztika tovább éljen. Az értékekkel jól kell gazdálkodni. Amit az elődök sok évtizedes kemény munkával felépítettek, nemzetközi elismertséget szereztek Szombathelynek, azt nem szabad lerombolni.

Pred nekaj tedni smo se v Sloveniji, na Cankovi, udeležili slovesnosti ob 130. obletnici rojstva Avgusta Pavla. Med nami posebej pozdravljam župana Cankove, gospoda Draga Vogrinčiča.

Častni gostje naše današnje konference so: Judita Pavel dr. Šimon, hči znanstvenika, polihistorja in učitelja v pravem pomenu besede Avgusta Pavla, redna članica Slovenske akademije znanosti in umetnosti prof. dr. Zinka Zorko, redni član Madžarske znanstvene akademije prof. dr. István Nyomárkay.

Mai nemzetközi konferenciánk díszvendégei: Dr. Simonné Pável Judit a tudós polihisztor és igaz tanár Pável Ágoston leánya, de itt van unokája, Vera is. Prof. Dr. Zinka Zorko a Szlovén Tudományos és Múvészeti Akadémia tagja, Prof. Dr. Nyomárkay István a Magyar Tudományos Akadémia tagja.

V eni izmed sekcij se bomo spomnili na prof. dr. Imreja $\mathrm{H}$. Tótha, ki je nedavno preminil. Imre $\mathrm{H}$. Tóth je bil velik častilec dela Avgusta Pavla. Avgusta Pavla so na Univerzi v Szegedu imenovali za habilitiranega univerzitetnega izrednega profesorja. Duhovni, strokovni in prijateljski stiki tudi danes povezujejo slavistiko v Szegedu in Sombotelu.

Hvala mojim navzočim kolegom: Istvánu Ferinczu, Mihályu Kocsisu in Gáborju Balázsu.

\section{Poštovani sudionici konferencije, dragi prijatelji!}

U proteklih 35 godina kroatistika je uvijek bila značajno zastupljena na našoj konferenciji. Osim domaćih kroatista jezikoslovaca, povjesničara i teoretičara književnosti, etnologa, ovdje su bili prisutni i ugledni profesori iz Zagreba, Osijeka, Rijeke, Zadra, Čakovca: Antica Menac, Dalibor Brozović, Mijo Lončarić, Josip Silić, Ivo Pranjković, Marko Samardžija, Marija Turk, Stjepan Hranjec, Mate Šimundić, Petar Šimunović, Đuro Blažeka, Irena Vodopija, Antun Šojat, Dijana Stolac, Mile Mamić, Stanislav Marijanović, Đuro Vidmarović, a mogao bih nabrajati i dalje.

Ali bili su prisutni i predstavnici ostalih južnoslavenskih jezika, kao primjerice Srbi, Bugari, Makedonci i drugi.

Zahvalan sam kolegama Ernestu Bariću, Stjepanu Blažetinu, koji su sedamnaest godina s Pečuškog sveučilišta dolazali u Sambotel i predavali, neovisno o tome je li padala kiša, puhao vjetar ili je snijeg zatrpao puteve.

Redovito su sudjelovali na našim konferencijama i znanstvenici iz Austrije: Nikola Benčić, Robert Hajszan Panonski, Gerhard Neweklowsky, Herta 
Lausegger, te iz Kanade profesor Tom Priestly. Više puta smo pozdravili slaviste iz Češke, Slovačke, Poljske i iz drugih zemalja.

\section{Poštovana konferencijo!}

Ovom prigodom želio bih se zahvaliti uime domaće slavistike gospodinu Istvánu Nyomárkayiju, akademiku, kome moraju biti zahvalni ne samo mađarski slavisti, nego i oni koji žive u inozemstvu. Desetljećima im je bio mentorom za doktorate i habilitacije i usmjeravao ih je na njihovom stručnom putu. I sambotelsko visoko školstvo je također mnogo profitiralo od njegovih stručnih, znanstvenih i ljudskih vrijednosti.

Most ezen a helyen szeretnék köszönetet mondani a hazai szlavisztika nevében Nyomárkay István akadémikus úrnak, akinek hálával tartozik sok hazai, de külföldön élő szlavista is. Évtizedeken át segítette a doktorálásra, habilitációra készülőket. Egyengette szakmai útjukat. A szombathelyi felsőoktatás pedig nagyon sokat profitált Nyomárkay professzor úr szakmai, tudományos és emberi értékeiből.

\section{Уважаемые участники и гости конференции!}

На всех одиннадцати Международных днях славистики русистика, украинистика и белорусистика занимали важное место. В Сомбатхее побывали сотни прекрасных специалистов из бывшего Советского Союза и бывших советских республик. За последние десятилетия в наших сборниках было опубликовано более четырёхсот научных статей. Высокий профессионализм характерен и для кафедр отечественных высших учебных заведений. Преподаватели-русисты-слависты Университета Этвеша Лоранда, Сегедского, Печского, Дебреценского университетов, Сегедского, Ньиредьхазского и Эгерского институтов (на сегодняшний день уже университетов) всегда принимали участие в конференции в Сомбатхее. Мы благодарны им за это!

Bio sam sretan kada sam prebrojio sudionike svih naših konferencija. Bilo ih je više od tisuću i petsto. Najbrojnija je bila peta konferencija sa svojih gotovo 450 sudionika. U zbornicima Studia Slavica Savariensia i u časopisu Biblioteca Slavica Savariensis objavljeno je blizu 2000 znanstvenih članaka, radova i monografija.

Najnovejša publikacija, ki smo jo izdali v spomin na rojstvo Avgusta Pavla, nosi naslov Skupna usoda v književnosti v zrcalu prevajalskega dela Avgusta Pavla. Delo, ki obsega 214 strani, je izšlo v XV. zvezku Bibliothece Slavice Savariensis. Izdaja vsebuje 6 študij, 15 slovenskih ljudskih balad, 14 slovenskih, hrvaških in srbskih junaških pesmi ter 14 izbranih del iz slovenske književnosti v madžarskem jeziku. Pavlove razlage besedil in zapiski so za 
prevajanje ljudskega slovstva in književnosti zelo koristni. Urednici izdaje sta Judita Pavel in Marija Kozar. Zahvaljujem se za njuno skrbno delo. Posebej se zahvaljujem Mariji Kozar Mukič, da je zagotovila sredstva za izdajo.

$\mathrm{Na}$ žalost nekaj bivših udeležencev naših konferenc ni več med nami. Število umrlih je 42. Spomnimo se nanje.

Nažalost, mnogi sudionici naše konferencije više nisu među nama. Njih je već četrdeset i dvoje.

Ovih je dana preminuo naš kolega iz Pečuha prof. Đuro Franković, kroatist i etnolog. Odajmo im počast minutom šutnje.

Sajnos, az egykori konferenciáinkon résztvevő kollégáink, professzoraink közül sokan már nem lehetnek közöttünk. Halottaink száma 42. Most emlékezzünk rájuk.

Köszönöm figyelmüket!

Hvala za pozornost!

Благодарю за внимание!

Hvala na pozornosti! 